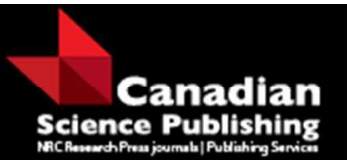

Canadian Journal of Forest Research Revue canadienne de recherche forestière

\title{
The effects of seed source health on whitebark pine (Pinus albicaulis) regeneration density after wildfire
}

\begin{tabular}{|r|l|}
\hline Journal: & Canadian Journal of Forest Research \\
\hline Manuscript ID: & cjfr-2015-0043.R2 \\
\hline Manuscript Type: & Article \\
\hline Complete List of Authors: & $\begin{array}{l}\text { Leirfallom, Signe; US Forest Service Rocky Mountain Research Station, } \\
\text { Missoula Fire Sciences Laboratory } \\
\text { Keane, Robert; USDA Forest Service } \\
\text { Tomback, Diana; University of Colorado Denver, Integrative Biology } \\
\text { Dobrowski, Solomon; University of Montana, College of Forestry and } \\
\text { Conservation }\end{array}$ \\
\hline Keyword: & $\begin{array}{l}\text { post-fire regeneration, wildfire, white pine blister rust, mortality, seed } \\
\text { sources }\end{array}$ \\
\hline \multicolumn{2}{|c}{} \\
\hline
\end{tabular}

\section{SCHOLARONE ${ }^{m}$ \\ Manuscripts}


1 The effects of seed source health on whitebark pine (Pinus albicaulis) regeneration density

2 after wildfire

3 Signe B. Leirfallom, Rocky Mountain Research Station ${ }^{1}$

4 Missoula Fire Sciences Laboratory, 5775 US Hwy 10 West, Missoula, MT 59808

5 Phone: (406) 546-4467, email: sigleirfall@gmail.com

7 Address correspondence to:

8 Robert Keane, Rocky Mountain Research Station

9 Missoula Fire Sciences Laboratory, 5775 US Hwy 10 West, Missoula, MT 59808

10 Phone: (406) 329-4846, Fax: (406)-329-4877, email: rkeane@fs.fed.us

12 Diana F. Tomback, Department of Integrative Biology, CB 171

13 University of Colorado Denver, P.O. Box 173364, Denver, CO 80217

14 Phone: (303) 556-2657, email: Diana.Tomback@ucdenver.edu

16 Solomon Dobrowski, College of Forestry and Conservation

17 University of Montana, 32 Campus Dr, Missoula, MT 59812

18 Phone: (406) 243-6068, email: solomon.dobrowski@umontana.edu

\footnotetext{
${ }^{1}$ Signe Leirfallom, Blackfoot Challenge PO Box 103, Ovando, MT 59854 signe@blackfootchallenge.org 


\section{Abstract}

Whitebark pine (Pinus albicaulis) populations are declining nearly rangewide from a

21 combination of factors including: mountain pine beetle (Dendroctonus ponderosae) outbreaks,

22 the exotic pathogen Cronartium ribicola, which causes the disease white pine blister rust, and

23 successional replacement due to historical fire exclusion practices. With high mortality in cone-

24 bearing whitebark pine, seed production may not be sufficient to support natural regeneration

25 after disturbance such as wildfire. Our objective was to examine the relationship between

26 whitebark pine seed source health and whitebark pine regeneration density in adjacent burns.

27 We sampled regeneration and seed source health in 15 burns within six national forests and three

28 Wilderness Areas in Montana, ranging from five to 23 years old. We found a significant,

29 positive relationship between seed source health and seedling density in adjacent burns. Natural

30 regeneration was sparse when the proportion of infested or dead whitebark pine in the seed

31 source exceeded 50\%. Factors that influenced the presence of whitebark pine regeneration

32 within a burn included both vegetation cover and potential solar radiation. Sites closer to seed

33 sources had higher probabilities of seedling occurrence, but seedlings were present throughout

34 most burns. Our results suggest that managers can prioritize restoration plantings of whitebark

35 pine seedlings after wildfire, based on the health status of the nearest seed sources.

36 Keywords: Pinus albicaulis; post-fire regeneration; wildfire; white pine blister rust; mountain

37 pine beetle 


\section{Introduction}

Whitebark pine (Pinus albicaulis) is widely distributed throughout the mountains of the

43 western United States and Canada but restricted to subalpine and treeline elevations (Arno and

44 Hoff 1990). Its seeds are an important food source for Clark's nutcrackers (Nucifraga

45 columbiana), which are the pine's primary seed dispersers (Hutchins and Lanner 1982; Tomback

46 1982), and other granivorous birds and mammals including grizzly bears (Ursus arctos

47 horribilis) (Tomback et al. 2001a). Whitebark pine serves as a foundation species in subalpine ecosystems by both structuring communities and stabilizing ecosystem function, and as a

49 keystone species by fostering biodiversity (Ellison et al. 2005; Tomback and Achuff 2010).

Invasive disease, native pest outbreaks, and fire exclusion practices have resulted in

51 major losses of this keystone subalpine tree species. The exotic pathogen white pine blister rust

52 (WPBR) (Cronartium ribicola) is present throughout most of the range of whitebark pine,

53 reducing cone production and killing trees (Schwandt et al. 2010; Tomback and Achuff 2010).

54 Estimates of WPBR infection levels are variable, but range from a low of 0-24\% in the Sierra

55 Nevada Range (Maloney 2011) to over 73\% in the northern US and southern Canadian Rocky

56 Mountains (Smith et al. 2008), with overall mortality doubling over the course of 20 years in the

57 Bob Marshall Wilderness in northwest Montana (Retzlaff et al. in prep). In the Canadian

58 Rockies, mean WPBR infection levels have risen from 42\% in 2003-2004 to 52\% in 2009

59 (Smith et al. 2008; 2013), with mortality increasing from $18 \%$ to $28 \%$ over the same time period.

60 In the Greater Yellowstone ecosystem, Bockino and Tinker (2012) found infection rates of over

$6180 \%$ in stands where WPBR was present. In addition, current climate-driven mountain pine

62 beetle (Dendroctonus ponderosae) outbreaks have killed cone-bearing whitebark pine at

63 unprecedented rates that could severely depress the regeneration potential of the species 
64 (Schwandt et al. 2010; Macfarlane et al. 2013). Finally, fire exclusion policies over the past 100

65 years are leading to successional replacement of whitebark pine by shade-tolerant conifers in

66 many areas (Keane et al. 1994; Murray et al. 2000). These threats were cited in whitebark pine's

67 recent listing as a candidate species under the United States Endangered Species Act (USFWS

68 2011) and listing as endangered in Canada under the Species at Risk Act (Government of Canada

69 2012).

The upper subalpine forests of the northern Rockies are generally fire-prone, with long

71 fire return intervals of 50-400 years for mixed severity fires (Arno and Hoff 1990; Morgan et al.

72 1994). Despite widespread fire exclusion practices, some fires are allowed to burn on federal

73 lands as "fire for resource benefit," while other wildfires burn in whitebark pine forests in spite

74 of suppression efforts (Parsons and Landres 1998). In many parts of the northern Rockies, the

75 effects of multiple stressors on whitebark pine stands raises several important questions: (1)

76 Given the widespread declining condition of the whitebark pine seed source, can whitebark pine

77 effectively regenerate in these burns? (2) Is there a measure of seed source health that managers

78 can use to decide which burned areas will need to be planted because of the loss of nearby seed

79 sources?

Whitebark pine regeneration depends upon where Clark's nutcrackers cache seeds and

81 the suitability of the cache site for seed germination and seedling establishment (Tomback 2001).

82 Because nutcrackers often cache seeds several kilometers away from a seed source, whitebark

83 pine is often one of the first trees to colonize large, stand-replacing burns (Tomback et al. 1990;

$841993 ; 2001 b)$. Additionally, burned areas tend to promote conditions favorable for whitebark

85 pine germination and establishment by providing many ground features, i.e., "nurse objects', that

86 provide protection from environmental exposure (Tomback et al. 1993; Lonergan et al. 2014), 
87 reduced litter cover (McCaughey and Weaver 1990), higher levels of soil nutrients (Perkins

88 2004), and reduced competition from other conifer species that are physiologically less tolerant

89 of environmental exposure (Maher and Germino 2006; Bansal et al. 2011). Evidence suggests

90 that whitebark pine seedlings growing in burns are more robust and have a greater chance to

91 reach cone-producing maturity. Perkins (2004) and Tomback et al. (2011) found higher growth

92 rates of whitebark pine seedlings that had established in burned areas as opposed to closed-

93 canopy forests, while Izlar (2007) and Lonergan et al. (2014) found higher survival of planted

94 seedlings on burned vs. unburned sites. In summary, fire is often favorable, and in most cases

95 necessary, for the long-term development of whitebark pine forest communities (Keane et al.

96 2012).

Recently, there has been concern among land managers that high-elevation burns may

98 actually be detrimental to certain populations of whitebark pine (Keane et al. 2012). If a seed

99 source adjacent to a burn produces few cones because mature trees are damaged or dead, Clark's

100 nutcrackers may not utilize the seed source, or much of the available seed could be consumed by

101 birds and mammals, resulting in low whitebark pine regeneration densities (McKinney and

102 Tomback 2007; McKinney et al. 2009; Barringer et al. 2012). Although some Clark’s

103 nutcrackers will transport seeds up to $30 \mathrm{~km}$ from a seed source to cache seeds within a defined

104 home range, most caching occurs locally (Lorenz et al. 2011). Managers need to know if

105 sufficient natural regeneration in a burn will occur so they can decide if they need to supplement

106 natural whitebark pine regeneration with planted seedlings (Keane et al. 2012). Regionally-

107 coordinated planting of whitebark pine seedlings grown from parents with demonstrated WPBR-

108 resistance is a benchmark of the Keane et al. (2012) whitebark pine restoration strategy; 
109 implementation of this strategy will be most efficient by considering natural whitebark pine 110 regeneration potential.

111 In this study, we evaluate natural whitebark pine regeneration patterns following wildfire

112 in areas in the US northern Rocky Mountains, given varying levels of damage and mortality in

113 nearby seed sources. It builds upon preliminary work completed by Tomback et al. (2008) in

114 four burns in or near the Bob Marshall Wilderness Complex, Montana. The central objective of

115 this study was to examine effects of seed source health (considering factors such as WPBR

116 infection and outbreaks of mountain pine beetle) on natural regeneration density in large, stand-

117 replacing burns (greater than $100 \mathrm{ha}$ ). We hypothesized that there may be a threshold in the

118 relationship between regeneration density and seed source health that would result from a level

119 of seed production that both attracts nutcrackers to a stand and provides sufficient seed for

120 caching (e.g., McKinney et al. 2009; Barringer et al. 2012). In addition, we evaluated site

121 conditions within the burns that may have influenced whitebark pine seedling establishment, and

122 described the health and age characteristics of whitebark pine seedlings within burns.

\section{Methods}

\section{Study areas}

125 Study areas were identified using extensive GIS analysis and the expertise of local land

126 managers as follows: we analyzed fire histories using MTBS (Monitoring Trends in Burn

127 Severity) data (Eidenshenk et al. 2007) and LANDFIRE vegetation data (LANDFIRE 1.1.0) to

128 find burned areas that met the following criteria: (a) burned terrain within the elevational range

129 of whitebark pine, (b) burns that were at least five years old to accommodate delayed

130 germination, (c) terrain burned by a stand replacement fire greater than 100 ha, and (d) burned 
131 area adjacent to at least 100 ha of unburned forest that contained seed-producing whitebark pine

132 trees at the time of the fire. After identifying possible study areas, we prioritized sites that were

133 accessible by foot or vehicle. We attempted to sample across a broad range of seed source health

134 conditions, from relatively intact stands with little whitebark pine mortality to highly impacted

135 stands with extensive mortality. All study areas were located in Montana, and ranged

136 geographically from the Flathead National Forest in the north to the Gallatin National Forest in

137 the south-central part of the state, and included three large Wilderness Areas (Figure 1; Table 1).

138 Each study area had two distinct sampling components with different sampling

139 objectives. The "seed source" component refers to a patch or stand of mature trees adjacent to or

140 within each sampled burn. Seed sources contained at least $2.0 \mathrm{~m}^{2} \mathrm{ha}^{-1}$ basal area of mature, live

141 whitebark pine (Barringer et al. 2012) (Table 1). Seed source boundaries generally followed the

142 burn perimeter, but we included patches of unburned, mature trees $>1$ ha within the burn as

143 potential seed sources. In these cases, we only sampled seed source characteristics in the largest

144 patch. We used GIS data including aerial photos, elevation data and LANDFIRE vegetation data

145 and field notes to delineate seed source boundaries for sampling and analysis purposes. The

146 "burned area" component refers to the sampled portion of the burn, adjacent to the seed

147 source(s), and meeting the criteria described above (stand-replacing burn within the elevational

148 distribution of whitebark pine).

\section{Seed Source Sampling}

Seed source stands were sampled using fixed-area, circular plots $\left(400 \mathrm{~m}^{2}, 11.28 \mathrm{~m}\right.$

151 radius). Seed source plots were located along a transect parallel to and $100 \mathrm{~m}$ from the edge of

152 the burn (Figure 2). At sites with multiple seed source patches, we sampled in the most 
153 prominent or largest patch. The first plot center was selected at random and each subsequent 154 plot center was located $50 \mathrm{~m}$ farther along the transect. We sampled four seed source plots at 155 each burn. In the preliminary study, Tomback et al. (2008) used $500 \mathrm{~m}^{2}$ belt transects to assess 156 seed source stands; in 2010 we switched to fixed area plots with nested seedling subplots to 157 better assess vegetation and regeneration characteristics in the seed source.

159 characteristics, recording UTM coordinates for each plot, slope, aspect, elevation, landform, 160 ground cover, and upper $(>3 \mathrm{~m}$ tall), mid $(>1 \mathrm{~m}$ and $<3 \mathrm{~m}$ tall $)$ and lower $(<1 \mathrm{~m}$ tall $)$ dominant 161 plant species. We also obtained measurements for mature trees following FIREMON protocol, 162 including the diameter at breast height (DBH), height, height to live crown base, species, and 163 health status (healthy, unhealthy, sick, dead) for each tree over $11.5 \mathrm{~cm} \mathrm{DBH}$ in the plot 164 boundary. For each living, mature whitebark pine tree we recorded the percent of crown killed 165 by WPBR, abiotic, or unknown factors. We confirmed mountain pine beetle damage by pitch 166 tubes and/or frass at the base of the tree. WPBR was confirmed by a combination of three or 167 more indicators including: stem or branch cankers, presence of aecial spore sacs, foliage 168 flagging, and/or rodent chewing. A tree was deemed healthy if it showed no sign of insect or 169 disease damage; unhealthy if non-lethal insect or disease damage was present (i.e., a branch 170 canker $>0.15 \mathrm{~m}$ from the bole or indication of an unsuccessful beetle attack); sick if the tree was 171 expected to die within five years or could no longer produce cones (i.e., active stem cankers, > $17250 \%$ crown kill, top kill or indication of a successful beetle attack). For dead whitebark pine 173 trees, we attempted to estimate if the trees were dead prior to or after the fire. We also tallied 174 live saplings (trees smaller than $11.5 \mathrm{~cm} \mathrm{DBH)}$ by $2.5 \mathrm{~cm} \mathrm{DBH}$ classes and recorded average 
175 height and crown base height. Finally, we tallied seedlings by species and $0.3 \mathrm{~m}$ height classes

176 in a nested fixed-area, circular plot $\left(40 \mathrm{~m}^{2}, 3.64 \mathrm{~m}\right.$ radius $)$.

\section{Burned Area Sampling}

Within a burn, we established fixed area, circular plots $\left(15 \mathrm{~m}^{2}, 2.18 \mathrm{~m}\right.$ radius $)$ along a set

179 of parallel transects that ran from the most prominent seed source stand toward the center of the

180 burn (Figure 2). We sampled between 30 and 80 plots at each burn with a grid resolution at or

181 near $100 \mathrm{~m}$ between both plots and transects. Tomback et al. (2008) sampled between 22 and 48

182 plots at each burn, with $25 \mathrm{~m}$ spacing between plots and transects. In 2010, we increased the

183 distance between plots to sample a larger portion of the burn. The distance and azimuth between

184 plots and transects were measured by cloth tape and compass, respectively. At each plot, we

185 recorded UTM coordinates, elevation, aspect, and slope, and visually estimated percent ground

186 cover and percent vegetation cover (vertically projected) according to FIREMON protocols.

187 We measured whitebark pine seedlings individually and tallied all other conifer seedlings and

188 saplings by $10 \mathrm{~cm}$ height class and species. For each whitebark pine seedling or sapling, we

189 sampled the additional variables of microsite (distance in meters to any major ground feature

190 such as a rock, stump, snag, etc.), presence or absence of WPBR symptoms, and seedling age

191 (estimated from branch whorls). If a plot was unburned or topographically inaccessible, we

192 offset the plot location by up to $20 \mathrm{~m}$, or skipped the plot entirely. We ran transects as far as

193 possible into each burn, but ceased sampling when we reached the lower elevational limits of

194 whitebark pine, or where the topography became inaccessible. 


\section{Data Analysis}

To analyze whitebark pine regeneration patterns, we developed two sets of models. One

197 model describes how overall whitebark pine regeneration density varies among sampled burns.

198 Whitebark pine regeneration increases over time following fire (Tomback et al. 2011); therefore,

199 we normalized the overall mean regeneration density at each site by the number of years since

200 fire at the time of sampling. This step was critical in isolating the effects of seed source health

201 on regeneration density. The second model describes microsite or environmental variables

202 within each burn that might influence the presence or absence (as opposed to density) of

203 regeneration at a given plot. As a result of the caching habits of the Clark's nutcracker,

204 whitebark pine seedlings often grow in clusters (Tomback 1982). For our purposes, each

205 seedling cluster was counted as one regeneration site. All data analyses were completed using 206 the software program R version 3.0.1 (R Core Team 2014).

\section{Regeneration density model selection}

Regeneration densities among burns were compared using simple, multiple and piecewise

209 linear regression. In using linear regression, we assumed that the response was a linear function

210 of the predictor variables, and that errors were normally distributed, independent and had equal

211 variance. To test these assumptions, we plotted and assessed the residuals from each model.

212 Numerous measures of seed source health were tested as potential predictors of seedling density

213 in the burn (see Table 2). These included: (1) mature whitebark pine basal area stratified by

214 health class (healthy, unhealthy, dead), (2) mean percent whitebark pine crown kill, (3) ratio of

215 subalpine fir basal area to whitebark pine basal area, (4) whitebark pine regeneration density in

216 the seed source, and (5) proportion of mature whitebark pine in each health class. Measures of 
217 overall site severity (mean heatload, potential solar radiation and burn severity- see description

218 below) were tested, but thrown out due to the geographic variation among study areas that

219 confounded the results. We used piecewise regression to test for a statistical threshold in the

220 relationship between regeneration density and seed source health, and tested quadratic forms of

221 predictor variables to look for curvilinear relationships. Predictor variables and interaction terms

222 were eliminated using t-tests; nested models were compared using F-tests in an analysis of

223 variance. We also used Spearman's rank order correlation to test whether whitebark pine

224 regeneration density in each burn was related to regeneration density in the adjacent seed source.

\section{Seedling probability model selection}

Because many of our burned area plots had no seedlings, we used non-parametric

227 analysis methods in evaluating site conditions within burns that might influence the occurrence

228 of whitebark pine seedlings at the plot level. Nearly all burned area plots had fewer than five

229 regeneration sites; therefore, we were unable to model relative differences in seedling density

230 within a burn. Instead, we built a logistic regression model to assess factors that influenced

231 seedling presence or absence at each plot. We used a generalized additive mixed model

232 (GAMM) to gain a visual understanding of the relationships between explanatory variables and

233 the probability of seedling occurrence. Then, we used generalized linear mixed models (GLMM;

234 binomial family and logit link (R Core Team 2014)) to further assess and refine the relationships

235 (Table 3). We did not include data from Tomback et al. (2008) in the seedling probability model

236 due to sampling resolution and protocol differences.

237 For both the GAMM and GLMM models, the burn study area was included as a random

238 effect to reflect coarse scale site differences, including time since fire. We included potential 
239 solar radiation, topographic convergence index (TCI), distance to seed source, percent vegetation

240 cover, heatload, and relative differenced normalized burn ratio (RdNBR) (i.e., burn severity) as

241 fixed effects (Table 3), which were calculated as follows: radiation, TCI and distance to seed

242 source were all obtained using ArcGIS (v.10.1). To calculate radiation and TCI, we used the

243 Solar Radiation and Flow Accumulation tools within the Spatial Analyst toolset on a digital

244 elevation model (DEM) of each burn. For the Solar Radiation tool, we updated the slope and

245 aspect to reflect field measurements, which more accurately depicted plot-level characteristics;

246 we used the default inputs in ArcGIS for sampling frequency, and calculated total solar radiation

$247\left(\mathrm{Wh} / \mathrm{m}^{2}\right)$ for an approximate growing season (May $1^{\text {st }}-$ October $31^{\text {st }}$ ). TCI was calculated using

248 the equation $t c i=\ln ($ flow accumulation/tan(slope) $)$. Distance to nearest seed source was

249 calculated using the Near tool, under the Proximity toolset. Seed sources included both mature

250 whitebark pine forests along the burn perimeter, and large patches ( $>1$ ha) of unburned forest

251 within the burn perimeter. Vegetation cover (\%) was estimated when plots were sampled. We

252 calculated heatload according to the methods of McCune and Keon (2002), and RdNBR values

253 (Miller and Thode 2009) were extracted from MTBS raster data for each burn.

We eliminated potential explanatory terms from the model using Wald z-tests $(\alpha=0.05)$,

255 and compared nested models using chi-squared tests in an analysis of variance to determine

256 whether progressively simpler models were statistically different from more complex models.

257 We tested the accuracy of the final model with a ten-fold cross-validation of the area under the

258 curve (AUC) statistic. The threshold for determining whether a predicted probability would

259 revert to seedling presence or absence was 0.32 , which was the prevalence of seedlings in the

260 combined dataset.

\section{$261 \quad$ Results}


In total, we sampled 15 burns across Montana, ranging from five to 23 years post-fire

263 (Figure 1). The basal area of live mature whitebark pine in the seed source ranged from 2.8 to

$26444.4 \mathrm{~m}^{2} \mathrm{ha}^{-1}$, above the threshold identified for a high likelihood $(0.75)$ of nutcracker visitation as

265 reported in Barringer et al. (2012). Whitebark pine seedling densities in the burns were highly

266 variable across and within sites (Figure 3, Table 4). Mean study area-level densities ranged from

2670 to 783 seedling clusters per hectare (Table 4), with individual plot-level densities ranging from

2680 to 6000 seedling clusters per hectare. When normalized by number of years since fire, mean

269 study area-level seedling densities ranged from 0 to 86 seedling clusters ha $^{-1}$ year $^{-1}$ (Table 4).

270 The Charlotte Peak burn on the Flathead National Forest had the highest overall seedling density,

271 but was also one of the oldest burns. When normalized by years since fire, the Pettengill burn on

272 the Beaverhead-Deerlodge National Forest had the highest seedling density, followed by the

273 Mussigbrod burn, also on the Beaverhead-Deerlodge. Two areas had no regeneration at the time

274 of sampling, Challenge and Wyman, but these were relatively recent burns (seven and five years

275 old respectively).

\section{Seed source health vs regeneration density}

277 We found that the greater the proportion of healthy whitebark pine trees in the seed

278 source, the greater the mean seedling density in the burn (Figure 4). While several measures of

279 seed source health were statistically significant predictors of seedling density in individual

280 models (Table 2), these variables were often redundant (Table 2); the best model included only

281 the proportion of mature whitebark pine in the seed source that were healthy (\%healthy).

282 Seedling density increased among burns in relation to \%healthy $\left(\mathrm{R}^{2}=0.54, P=0.001\right.$, Figure

$2834 \mathrm{a})$, but the $\mathrm{R}^{2}$ and the residuals were improved by adding a quadratic term, $\%$ healthy $\mathrm{y}^{2}\left(\mathrm{R}^{2}=\right.$

$2840.70, P=0.0002$, Figure $4 \mathrm{~b}$, residuals shown in Figure 5). In a piecewise regression model, we 
285 identified a potential threshold of 50\% healthy trees, above which, seedling density increased at a

286 higher rate (Figure 4c). However, there were too few data points at high values of \%healthy to

287 determine the robustness of this threshold. We found no significant correlation between

288 normalized whitebark pine regeneration density in burned areas and regeneration density in

289 adjacent seed sources $\left(\mathrm{r}_{\mathrm{s}}(11)=-0.38, p=0.25\right)$.

\section{Seedling occurrence within burns}

We built a model that addresses some of the microsite factors that might influence

292 seedling survival and establishment in burns after nutcracker caching (Table 3). We found that

293 potential solar radiation, distance to seed source and vegetation cover were significant predictors

294 of whitebark pine seedling presence within the burn (Figure 6, Table 3). The probability of

295 seedling presence decreased with increasing distance to seed source up to about $600 \mathrm{~m}$, but then

296 increased between 600 and $1200 \mathrm{~m}$ (the limits of the study) although with a high level of

297 uncertainty, given sparse sampling at this distance (Figure 6a). The probability of seedling

298 presence increased up to $30 \%$ vegetation cover, but decreased above that (Figure 6b). Finally,

299 probability of seedling presence decreased with increasing potential solar radiation (Figure 6c).

300 The mean AUC of this model was 0.75 (standard deviation of 0.05 ), indicating that the model

301 had average skill in predicting seedling presence.

\section{Whitebark pine seedling health and age}

303 Out of 376 whitebark pine regeneration sites measured for this study, only three percent

304 showed symptoms of WPBR. About $54 \%$ of seedlings were found within $0.5 \mathrm{~m}$ of a ground

305 feature, such as a rock, log, stump or snag. Seedlings older than 15 years were difficult to age

306 accurately using branch whorls, so we only analyzed age-structure of seedlings in burns that 
307 occurred after the year 2000. In these six burns, we found that very few sampled, established 308 seedlings germinated until at least four years post-fire (Figure 7). Across the five areas that 309 burned in 2000 (Beaver Creek, Fall Fork, Monture, Mussigbrod and Skalkaho), we found that 310 only $2 \%$ of the sampled, established seedlings germinated in the first two years following fire;

$31111 \%$ germinated between three and four years post-fire; $73 \%$ of seedlings germinated between 312 five and ten years post-fire; and the remaining $14 \%$ germinated between 11 and 13 years post-

313 fire (the limit of the data). We also evaluated seedling ages within the same five burns to look

314 for regional germination trends that would indicate masting events, but did not find any patterns.

315 The Mussigbrod fire had high germination in the year 2009, but this pattern was not evident in

316 the Fall Fork fire, which occurred in the same geographic region. Interestingly, the Monture fire

317 showed almost no germination after the year 2006, which coincides with the start of an observed 318 mountain pine beetle outbreak in the seed source.

319 Discussion

Given the precipitous decline in whitebark pine in many regions, and the importance of

321 fire to successional whitebark pine communities, the question of whether whitebark pine is

322 regenerating at historical rates becomes an important management issue. Several studies have

323 explored whitebark pine regeneration after fire (Tomback et al. 1993; 1995; Perkins 2004;

324 Moody 2006), but none have examined the relationship between whitebark pine seed source

325 health and whitebark pine regeneration density in large burns. Overall, we found that seed

326 source health predicted regeneration density and that distance to seed source, vegetation cover,

327 and potential solar radiation were significant predictors of whitebark pine seedling presence

328 within a burn. 


\section{Seed source health vs regeneration density}

While natural whitebark pine regeneration was present throughout most of the sampled

331 burns, seedling density increased in areas with healthier seed sources, likely an indication of

332 greater nutcracker visitation and seed-caching. The high variability in regeneration across our

333 study sites (Figure 3 and Table 4) likely reflects bird-mediated seed dispersal and is inherent in

334 this type of data. Barringer et al. (2012) found that regeneration density in unburned stands was

335 related to the health and basal area of mature whitebark pine in the stand, but it was not clear that

336 the relationship would hold for adjacent burned areas, because Clark's nutcrackers could

337 transport seeds into burns from stands as far as $30 \mathrm{~km}$ away (Lorenz et al. 2011). Our results

338 suggest that nutcrackers harvest seeds most often from local seed sources for caching in adjacent

339 burns.

The best indicator of seedling density in the adjacent burn was the proportion of mature

341 whitebark pines that were healthy (\%healthy). "Healthy" whitebark pine forests are diverse in

342 structure. Open-grown stands might have low basal areas, but cone production (therefore seed

343 availability) might be high in the large, well-spaced crowns. This pattern is evident in a

344 comparison of two of our sampling sites - Mussigbrod and Fall Fork - which burned in the same

345 year, have similarly healthy seed sources (comprised of $\sim 60 \%$ healthy whitebark pine), and are

346 relatively close geographically. At Fall Fork, the seed source was dominated by whitebark pine

347 growing in a dense, closed stand, while the seed source at Mussigbrod was open-grown and

348 park-like. The basal area of mature whitebark pine in the Fall Fork seed source was more than

349 twice that of Mussigbrod, but regeneration densities in the burn were essentially the same at both

350 sites (Tables 1 and 4). Therefore, a qualitative measure such as \%healthy may be an appropriate 
351 indicator of seedling density across different forest types, in the absence of measuring actual 352 cone-production.

\section{Factors affecting seedling occurrence}

354 Numerous factors influence whitebark pine seed dispersal and subsequent seedling 355 establishment at a given location. The magnitude and effectiveness of seed dispersal by the

356 Clark's nutcracker are the most important, yet the most difficult to measure. Given this caveat, 357 we identified several variables that influence the probability of seedling presence at a given site.

358 Whitebark pine seedling occurrence generally decreased further from seed sources, but this 359 pattern was inconsistent throughout the dataset (Figure 6a). Tomback et al. (1990) found that 360 seedling density declined as distance from the whitebark pine seed source increased (up to 3650 $361 \mathrm{~m})$, but this decline was also associated with an elevational loss of approximately $380 \mathrm{~m}$. While 362 we intentionally sampled the largest, most continuous stand-replacing burns within our study 363 area, it was a challenge to find portions of a burn that were greater than $600 \mathrm{~m}$ from a seed 364 source, especially after accounting for patches of unburned seed source that reside within the

365 burn perimeter. Most subalpine burns are spatially patchy across the landscape, which will result 366 in some spatial heterogeneity in both whitebark pine seed sources and regeneration patterns (see 367 Kolden et al. 2012).

We found that intermediate amounts of vegetation cover were associated with increased

369 whitebark pine seedling occurrence in sampled burns, but dense vegetation cover decreased

370 probability of seedling occurrence (Figure 6b). Although we cannot know the percent vegetation

371 cover under which seedlings first germinated in this study, our results suggest that the presence

372 of some cover has facilitated survival. This finding is consistent with previous research 
373 (McCaughey and Weaver 1990; Maher and Germino 2006; Tomback et al. 2011), indicating that

374 while whitebark pine is more tolerant of exposure than other subalpine conifers, it is more likely

375 to establish under partial-shade conditions. Tomback et al. (2011) found that some vegetation

376 cover, in addition to woody debris cover, increased survival of seedlings that germinated after

377 the 1988 Yellowstone Park fires; however, dense residual vegetation in the understory on

378 moderately burned sites limited seedling survival. In addition to reducing competition from other

379 conifers, burns provide an abundance of ground features, such as fallen trees, branches and

380 stumps and low vegetation cover that can help protect new whitebark pine seedlings from

381 desiccation and cold exposure. Seedling establishment is also influenced by changes in

382 topography, which impacts the amount of solar radiation at a given site. Whitebark pine seedling

383 occurrence decreased as potential solar radiation increased; this pattern is not surprising, because

384 higher amounts of solar radiation may lead to lower soil moisture and increased seedling

385 mortality (Maher et al. 2005), especially on an exposed site post-fire.

Our results show that whitebark pine establishes for many years following a fire, which is

387 consistent with previous findings (e.g. Tomback et al. 1993; 1995; 2001b, and 2011). Only 13\%

388 of the seedlings we sampled germinated in the first four years following a fire; Tomback et al.

389 (2001b) found a similar pattern in a more fine-scale regeneration analysis of the 1988

390 Yellowstone Park fires. In their study, the first whitebark pine seedlings didn't emerge until

391 three years post-fire, following a masting event and two winters of seed dormancy. In general, it

392 takes at least five years for whitebark pine to begin populating a burn, so immediate post-fire

393 assessments are unnecessary. 


\section{Management implications}

Our results indicate that in burned areas where more than $50 \%$ of the adjacent whitebark pine seed source is damaged or dead, low seed availability may limit natural regeneration

397 potential $\left(<300\right.$ seedling clusters $\mathrm{ha}^{-1}$ ten years post-fire). Given that older, taller seedlings are 398 more susceptible to WPBR infection, seedling and sapling mortality will likely increase over 399 time in areas where WPBR is present (Tomback et al. 1995), which may prevent these stands 400 from becoming productive, cone-producing forests. Long-term monitoring of whitebark pine 401 regeneration at these sites is necessary to confirm or refute this trend, as WPBR-susceptibility 402 and resistance are highly variable at local and regional scales (Mahalovich et al. 2006).

The Keane et al. (2012) whitebark pine restoration strategy suggests a target density of 404 approximately 250 seedlings ha ${ }^{-1}$ (6.1 m spacing) for optimal long-term forest structure. This 405 target is based on planted WPBR-resistant seedlings with an assumed survival rate of 50\%, and 406 will vary based on stand-level forest structure objectives. Target densities for natural 407 regeneration need to be adjusted to local seed source WPBR infection and resistance levels, 408 which will ultimately determine seedling survival. Managers can use WPBR-resistance data 409 from nearby plus trees (trees with demonstrated WPBR-resistance, see Mahalovich and 410 Dickerson (2004)) to estimate WPBR-resistance in natural regeneration, as it will usually be a 411 mix of putatively resistant and susceptible seedlings. If managers choose to supplement natural 412 regeneration with planted seedlings, they should utilize seedlings grown from screened parents 413 containing multigenic partial WPBR-resistance (Keane et al. 2012), because there has been a 414 trend in increased incidence of WPBR infection among trees in all regions (Maloney et al. 2012;

415 Smith et al. 2013). It is also important to note that regeneration rates are but one of the key vital 416 rates which influence population growth rates following wildfire. While regeneration density and 19 
417 mortality are important indicators of potential forest structure, managers should also consider

418 long-term adult growth rates, fecundity, masting frequency and mortality rates as WPBR

419 infection levels stabilize or increase (Maloney et al. 2012). Long-term monitoring of natural

420 regeneration characteristics, planted seedling survivorship, and seed source health is critical in

421 developing effective restoration plans (Keane et al. 2012).

Fire managers are often faced with conflicting issues when determining whether or not to

423 suppress high elevation fire. On one hand, fire is an integral process in shaping the subalpine

424 landscape. On the other hand, fires that pose a risk to humans, structures and other development,

425 historical preservation and other management objectives might preclude "letting it burn." Given

426 that burned areas provide the conditions most favorable for whitebark pine seedling

427 establishment and growth to reproductive maturity, suppressing high elevation fire for the benefit

428 of whitebark pine could be counter-productive. Patches of burns that are not regenerating will

429 create landscape heterogeneity over time and may help limit the size of future disturbance. Fire

430 suppression on a small scale that leads to the protection of healthy seed source stands and plus

431 trees or small islands of subalpine habitat that hold special recreational or wildlife value

432 comprises the best fire management response in whitebark pine forests (Keane et al. 2012).

\section{Acknowledgements}

434 We are grateful to Steve Wirt, retired Flathead National Forest, and Ward McCaughey, 435 retired USDA Forest Service Rocky Mountain Research Station, for their contributions to the 436 study. For field work in 2004-2005, we thank Deb Mucklow, Larry Schutz, Bob Jeligson and 437 Tad Wehunt of the Flathead National Forest, Spotted Bear Ranger District, for housing, logistical 438 and pack support. Dave Warder, Mary Lou Zimmerman, Kate Kendall, Susan Kemper, Marcie 
439 Johnson, Jennie Birdsall, and Marcia Youngman provided volunteer field support or logistic 440 support during the study. Students from the University of Colorado Denver - Jennifer Berg, 441 Kara Stevens, David Meyers, Kristen Grompone, Ashley East, Daniel Maddox, David Meyers 442 and Mario Perez - provided field assistance or help with data analysis in 2004-2006. For field 443 work in 2010-2013, we thank Bob Hutton and Ben Wilson of the Beaverhead-Deerlodge 444 National Forest, and Wendel Hann, retired USDA Forest Service, for pack and logistical support. 445 We also thank the Beaverhead-Deerlodge, Flathead, Gallatin, Helena, Lolo and Lewis and Clark

446 National Forests for hosting us in the backcountry. We are grateful to the field crew - Sarah 447 Flanary, Jay Fronden, Violet Holley, Brian Izbicki, Christy Lowney, Aaron Sparks, Greg Cohn, 448 Edith Dooley and Colin Hunton, all current or former employees of the USDA Forest Service, 449 Rocky Mountain Research Station Fire Sciences Lab. Andrew Larson and Anna Sala of the 450 University of Montana provided helpful reviews of this manuscript, as did two anonymous 451 reviewers. Finally, we are all grateful to the USDA Forest Service, Rocky Mountain Research 452 Station Fire Sciences Lab and Forestry Sciences Lab for funding and logistical support and to the 453 University of Colorado Denver and University of Montana for general project support.

\section{References}

Arno, S.F., Hoff, R. 1990. Pinus albicaulis Engelm. Whitebark pine. Silvics of North America. Vol. I. Conifers. Agriculture Handbook, pp. 268-279. USDA Forest Service.

Bansal, S., Reinhardt, K., Germino, M.J. 2011. Linking carbon balance to establishment patterns: comparison of whitebark pine and Engelmann spruce seedlings along an herb cover exposure gradient at treeline. Plant Ecology 212:219-228. 
Barringer, L.E., Tomback, D.F., Wunder, M.B., McKinney, S.T., 2012. Whitebark pine stand condition, tree abundance, and cone production as predictors of visitation by Clark's nutcracker. Plos One7, e37663.

Bockino, N.K., Tinker, D.B. 2012. Interactions of White Pine Blister Rust and Mountain Pine Beetle in Whitebark Pine Ecosystems in the Southern Greater Yellowstone Area. Natural Areas Journal 32(1):31-40.

Eidenshenk, J., Schwind, B, Brewer, K, Zhu, Z.L., Quayle, B, Howard, S. 2007. A Project for Monitoring Trends in Burn Severity. Fire Ecology Special Issue 3(1):3-21.

Ellison, A.M., Bank, M.S., Clinton, B.D., Colburn, E.A., Elliott, K., Ford, C.R., Foster, D.R., Kloeppel, B.D., Knoepp, J.D,, Lovett, G.M., Mohan, J., Orwig, D.A., Rodenhouse, N.L., Sobczak, W.V., Stinson, K.A., Stone, J.K., Swan, C.M., Thompson, J., Von Holle, B., and Webster, J.R. 2005. Loss of foundation species: consequences for the structure and dynamics of forested ecosystems. Frontiers in Ecology and the Environment 3:479-486.

Government of Canada. 2012. Order amending Schedule 1 to the Species at Risk Act. Canada Gazette Part II, Vol 146, No. 14, SOR/2012-113, June 20, 2012 [online]. Available from http://www.sararegistry.gc.ca/virtual_sara/files/orders/g2-14614i_e.pdf.

Hutchins, H.E., Lanner, R.M. 1982. The central role of Clark's Nutcracker in the dispersal and establishment of Whitebark pine. Oecologia 55:192-201.

Izlar, D.K. 2007. Assessment of whitebark pine seedling survival for Rocky Mountain plantings. M.Sc. thesis, Department of Forestry, University of Montana, Missoula, MT, USA. 
Keane, R., Morgan, P., Menakis, J. 1994. Landscape assessment of the decline of whitebark pine (Pinus albicaulis) in the Bob Marshall Wilderness Complex, Montana, USA. Northwest Science 68:213-229.

Keane, R.E., Tomback, D., Aubry, C., Bower, A., Campbell, E., Cripps, C., Jenkins, M., Mahalovich, M.F., Manning, M., McKinney, S., Murray, M., Perkins, D., Reinhart, D., Ryan, C., Schoettle, A., Smith, C. 2012. A range-wide restoration strategy for whitebark pine (Pinus albicaulis). General Technical Report RMRS-GTR-279. USDA Forest Service Rocky Mountain Research Station, Fort Collins, CO, USA.

Kolden, C.A., Lutz, J.A., Key, C.H., Kane, J.T., van Wagtendonk, J.W. 2012. Mapped versus actual burned area within wildfire perimeters: Characterizing the unburned. Forest Ecology and Management 286:38-47.

LANDFIRE: LANDFIRE 1.1.0. Existing Vegetation Type layer. U.S. Department of the Interior, Geological Survey. [Online]. Available: http://landfire.cr.usgs.gov/viewer/ [2010, January 8].

Lonergan, E.R., Cripps, C.L., Smith, C.M. 2014. Influence of site conditions, shelter objects, and ectomycorrhizal inoculation on the early survival of whitebark ine seedlings planted in Waterton Lakes National Park. Forest Science 60(3):603-612

Lorenz, T.J., Sullivan, K.A., Bakian, A.V., Aubry, C.A. 2011. Cache-site selection in Clark's nutcracker (Nucifraga Columbiana). Auk 128:237-247.

Lutes, D.C., Keane, R.E., Caratti, J.F., Key, C.H., Benson, N.C., Sutherland, S., Gangi, L.J. 2006. FIREMON: fire effects monitoring and inventory system. General Technical 
Report RMRS-GTR-164-CD, USDA Forest Service, Rocky Mountain Research Station, Fort Collins, CO, USA.

Macfarlane, W.W., Logan, J.A., Kern, W.R. 2013. An innovative aerial assessment of Greater Yellowstone Ecosystem mountain pine beetle-caused whitebark pine mortality. Ecological Applications 23(2):421-437.

Mahalovich, M.F., Dickerson, G.A. 2004. Whitebark pine genetic restoration program for the Intermountain West (United States). Edited by: Sniezko, R.A., Samman, S., Schlarbaum, S.E., Kriebel, H.B. 2004. Breeding and genetic resources of five-needle pines: growth, adaptability and pest resistance, 23-27 July 2001, Medford, OR, USA. IUFRO Working Party 2.02.15. Proceedings RMRS-P-32, USDA Forest Service, Rocky Mountain Research Station, Fort Collins, CO, USA.

Mahalovich, M.F., Burr, K.E., Foushee, D.L. 2006. Whitebark Pine Germination, Rust Resistance, and Cold Hardiness Among Seed Sources in the Inland Northwest: Planting Strategies for Restoration. Edited by: Riley, L.E., Dumroese, R.K., Landis, T.D. 2006. National proceedings: Forest and Conservation Nursery Associations - 2005. Proceedings RMRS-P-43, USDA Forest Service, Rocky Mountain Research Station, Fort Collins, CO, USA.

Maher, E.L., Germino, M.J. 2006. Microsite differentiation among conifer species during seedling establishment at alpine treeline. Ecoscience 13:334-341.

Maher, E.L., Germino, M.J., Hasselquist, N.J. 2005. Interactive effects of tree and herb cover on survivorship, physiology, and microclimate of conifer seedlings at the alpine tree-line ecotone. Canadian Journal of Forest Research 35(3):567-574. 
Maloney, P.E. 2011. Incidence and distribution of white pine blister rust in the high-elevation forests of California. Forest Pathology 41(4):308-316.

Maloney, P.E., Vogler, D.R., Jensen, C.E., Delfino Mix, A. 2012. Ecology of whitebark pine populations in relation to white pine blister rust infection in subalpine forests of the Lake Tahoe Basin, USA: Implications for restoration. Forest Ecology and Management 280:166-175.

McCaughey, W.W., Weaver, T. 1990. Biotic and microsite factors affecting whitebark pine establishment. General Technical Report INT-270, USDA Forest Service, Bozeman, Montana, USA. Pages 140-150.

McKinney, S.T., Tomback, D.F. 2007. The influence of white pine blister rust on seed dispersal in whitebark pine. Canadian Journal of Forest Research 37:1044-1057.

McKinney, S.T., Fiedler, C.E., Tomback, D.F. 2009. Invasive pathogen threatens bird-pine mutualism: implications for sustaining a high-elevation ecosystem. Ecological Applications 19(3):597-607.

McCune, B., Keon, D. 2002. Equations for potential annual direct incident radiation and heat load. Journal of Vegetation Science 13:603-606.

Miller, J.D., Thode, A.E. 2009. Quantifying burn severity in a heterogeneous landscape with a relative version of the delta Normalized Burn Ratio (dNBR). Remote Sensing of Environment, 109(1):66-80. 
Moody, R.J. 2006. Post fire regeneration and survival of whitebark pine (Pinus albicaulis Engelm). M.Sc. thesis, Department of Forestry, The University of British Columbia, Vancouver, B.C.

Morgan, P., Bunting, S.C., Keane, R.E., Arno, S.F. 1994. Fire ecology of whitebark pine (Pinus albicaulis) forests in the Rocky Mountains, USA. Pages 136-142 in Proceedings of the international symposium Subalpine stone pines and their environment: The status of our knowledge, St. Moritz, Switzerland.

Murray, M.P., Bunting, S.C., Morgan, P. 2000. Landscape trends (1753-1993) of whitebark pine (Pinus albicaulis) forests in the west Big Hole range of Idaho/Montana, USA. Arctic, Antarctic and Alpine Research: 32(4):412-418.

Parsons, D. J., Landres, P.B. 1998. Restoring natural fire to wilderness: How are we doing? Tall Timbers Fire Ecology Conference 20:366-374.

Perkins, J.L. 2004. Pinus albicaulis regeneration after fire. Dissertation, Department of Forestry, University of Montana, Missoula, MT, USA.

R Core Team. 2014. R: A language and environment for statistical computing. R Foundation for Statistical Computing, Vienna, Austria. URL http://www.R-project.org/.

Retzlaff, M.J., Leirfallom, S., Keane, R.E. 2015. A 20 year reassessment of the health and status of Whitebark pine (Pinus albicaulis) forests in the Bob Marshall Wilderness complex, Montana, USA. Manuscript in preparation. 
Schwandt, J.W., Lockman, I.B., Kliejunas, J.T., Muir, J.A. 2010. Current health issues and management strategies for white pines in the western United States and Canada. Forest Pathology 40:226-250.

Smith, C., Wilson, B.C., Rasheed, S., Walker, R.C., Carolin, T., Shepherd, B. 2008. Whitebark pine and white pine blister rust in the Rocky Mountains of Canada and northern Montana. Canadian Journal of Forest Research 38:982-995.

Smith, C., Shepherd, B., Gillies, C., Stuart-Smith, J. 2013. Changes in blister rust infection and mortality in whitebark pine over time. Canadian Journal of Forest Research 43:90-96.

Tomback, D.F. 1982. Dispersal of whitebark pine seeds by Clark's nutcracker: a mutualism hypothesis. Journal of Animal Ecology 51:451-467.

Tomback, D.F. 2001. Clark's nutcracker: Agent of regeneration. Edited by: Tomback, D.F., Arno, S.F., Keane, R.E. Whitebark pine communities: ecology and restoration. Island Press, Washington DC, USA, pp. 89-104.

Tomback, D.F., Achuff, P. 2010. Blister rust and western forest biodiversity: Ecology, values, and outlook for white pines. Forest Pathology 40(3-4):186-225.

Tomback, D.F., Hoffman, L.A., Sund, S.K. 1990. Coevolution of whitebark pine and nutcrackers: implications for forest regeneration. General Technical Report INT-270, USDA Forest Service, Bozeman, Montana, USA, pp. 118-129.

Tomback, D.F., Sund, S.K., Hoffman, L.A. 1993. Postfire regeneration of Pinus albicaulis: height-age relationships, age structure, and microsite characteristics. Canadian Journal of Forest Research 23:113-119. 
Tomback, D.F., Clary, J.K., Koehler, J., Hoff, R.J., Arno, S.F. 1995. The effects of blister rust on post fire regeneration of whitebark pine: the Sundance burn of northern Idaho (USA). Conservation Biology 9(3):654-664.

Tomback, D.F., Anderies, A.J., Carsey, K.S., Powell, M.L., Mellmann-Brown, S. 2001b. Delayed seed germination in whitebark pine and regeneration patterns following the Yellowstone fires. Ecology. 82(9): 2587-2600.

Tomback, D.F., Arno, S.F., Keane, R.E., editors. 2001a. Whitebark pine communities: Ecology and Restoration. Island Press, Washington, DC USA.

Tomback, D.F., Wirt, S., McCaughey, W.M., Keane, R.E. 2008. Preliminary pattern of investigation of the magnitude and time-frame of post-fire whitebark pine regeneration within selected areas in the Bob Marshall Wilderness Area and adjacent lands. Joint Venture Agreement Final Report on file at Missoula Fire Sciences Laboratory, P.O. 5775 Hwy 10 West Missoula, MT JVA 03-JV-112222022-251, USDA Forest Service, Missoula, MT.

Tomback, D.F., Schoettle, A.W., Perez, M.J., Grompone, K.M., Mellmann-Brown, S. 2011. Regeneration and survival of whitebark pine after the 1988 Yellowstone Fires. Edited by: Keane, R.E., Tomback, D.F., Murray, M.P., Smith, C.M. The future of high-elevation, five-needle white pines in western North America: Proceedings of the High Five Symposium. 28-30 June 2010, Missoula, MT. Proceedings RMRS-P-63. USDA Forest Service, Rocky Mountain Research Station, Ft. Collins, CO, USA, pp. 66-68. 
U.S. Fish and Wildlife Service. 2011. Endangered and threatened wildlife and plants, 12-month finding on a petition to list Pinus albicaulis as endangered or threatened with critical habitat. Federal Register 76(138):42631-42654.

\section{Tables}

Table 1. Summary of subalpine burns in Montana, USA sampled for this study, in order of decreasing seed source health. WBP refers to whitebark pine.

\begin{tabular}{|c|c|c|c|c|c|c|c|}
\hline Burn name & $\begin{array}{c}\text { Year } \\
\text { burned }\end{array}$ & $\begin{array}{c}\text { Size of } \\
\text { burn } \\
\text { (ha) }\end{array}$ & $\begin{array}{l}\text { WBP basal } \\
\text { area* in } \\
\text { seed source } \\
\left(\mathrm{m}^{2} \mathrm{ha}^{-1}\right) \\
\end{array}$ & $\begin{array}{c}\text { Healthy } \\
\text { WBP in } \\
\text { seed source } \\
(\%) \\
\end{array}$ & $\begin{array}{c}\text { Mean WBP } \\
\text { seedling density } \\
\text { in seed source } \\
\left(\text { clusters ha }{ }^{-1}\right) \\
\end{array}$ & $\begin{array}{c}\text { SD WBP } \\
\text { seedling density } \\
\text { in seed source } \\
(\text { clusters ha-1) } \\
\end{array}$ & $\begin{array}{c}\text { Study location } \\
\text { (Montana, USA) } \\
\text { NF }=\text { National Forest }\end{array}$ \\
\hline Pettengill & 2007 & 6,192 & 12.3 & 65.1 & 1174 & 738 & Beaverhead-Deerlodge NF \\
\hline Mussigbrod & 2000 & 11,178 & 20.5 & 62.2 & 185 & 371 & $\begin{array}{l}\text { Anaconda-Pintler Wilderness, } \\
\text { Beaverhead-Deerlodge NF }\end{array}$ \\
\hline Fall Fork & 2000 & 850 & 44.4 & 60.5 & 124 & 143 & $\begin{array}{l}\text { Anaconda-Pintler Wilderness, } \\
\text { Beaverhead-Deerlodge NF }\end{array}$ \\
\hline Red Owl & 1984 & 591 & NA & 43.3 & NA & NA & Flathead NF \\
\hline Charlotte Pk & 1985 & 2,385 & 23.8 & 40.9 & NA & NA & $\begin{array}{c}\text { Bob Marshall Wilderness, } \\
\text { Flathead NF }\end{array}$ \\
\hline Beaver Creek & 2000 & 4,323 & 5.5 & 26.7 & 1297 & 865 & Gallatin NF \\
\hline Wyman & 2007 & 14,374 & 4.6 & 26.7 & 988 & 1159 & Beaverhead-Deerlodge NF \\
\hline Bighorn Lk & 1988 & 80,961 & 3.6 & 22.5 & 2224 & 1555 & $\begin{array}{c}\text { Scapegoat Wilderness, Helena } \\
\text { NF }\end{array}$ \\
\hline Skalkaho & 2000 & 3,027 & 16.5 & 20.3 & 432 & 371 & Bitterroot NF \\
\hline Monitor Mtn & 1988 & 80,961 & 2.8 & 16.7 & 3645 & 3991 & $\begin{array}{c}\text { Scapegoat Wilderness, Lewis } \\
\text { and Clark NF }\end{array}$ \\
\hline Gates Park & 1988 & 22,093 & 10 & 14 & 0 & 0 & $\begin{array}{l}\text { Bob Marshall Wilderness, } \\
\text { Lewis and Clark NF }\end{array}$ \\
\hline Challenge & 1998 & 3,846 & 3.9 & 13.3 & NA & NA & Flathead NF \\
\hline Ann & 1994 & 1,265 & 3.1 & 7.7 & 556 & 816 & Bitterroot NF \\
\hline Monture & 2000 & 9,624 & 5.2 & 2.7 & 1977 & 2917 & $\begin{array}{c}\text { Bob Marshall Wilderness, } \\
\text { Flathead NF }\end{array}$ \\
\hline Helen Creek & 1994 & 2,846 & 19.6 & 1.6 & NA & NA & $\begin{array}{c}\text { Bob Marshall Wilderness, } \\
\text { Flathead NF }\end{array}$ \\
\hline
\end{tabular}


Table 2. Summary of linear regression models for the mean whitebark pine regeneration density (seedling clusters $\mathrm{ha}^{-1} \mathrm{yr}^{-1}$ ) among 15 burn study areas in Montana, USA; WBP refers to whitebark pine, SAF refers to subalpine fir, BA refers to basal area $\left(\mathrm{m}^{2} \mathrm{ha}^{-1}\right)$. Final model is in bold; also shown are correlations between measures of seed source health.

\begin{tabular}{|c|c|c|c|c|}
\hline Model predictor variable(s) & Coefficients & SE & $\mathbf{R}^{2}$ & $P$-value \\
\hline Healthy WBP BA $\left(\mathrm{m}^{2} \mathrm{ha}^{-1}\right)$ & 1.397 & 0.60 & 0.25 & $0.037 *$ \\
\hline Healthy+unhealthy WBP BA $\left(\mathrm{m}^{2} \mathrm{ha}^{-1}\right)$ & 0.998 & 0.53 & 0.16 & 0.085 \\
\hline Dead WBP BA $\left(\mathrm{m}^{2} \mathrm{ha}^{-1}\right)$ & -1.014 & 0.86 & 0.02 & 0.262 \\
\hline Mean WBP crown kill (\%) & -0.889 & 0.23 & 0.48 & $0.002 * *$ \\
\hline Ratio of live SAF BA to live WBP BA $\left(\mathrm{m}^{2} \mathrm{ha}^{-1}\right)$ & -9.789 & 7.39 & 0.07 & 0.218 \\
\hline WBP regeneration density in seed source (clusters ha $\left.{ }^{-1}\right)^{\dagger}$ & -0.009 & 0.01 & 0.07 & 0.222 \\
\hline \%healthy WBP & 0.850 & 0.20 & 0.54 & $0.001 * * *$ \\
\hline$(\% \text { healthy WBP })^{2}$ & 0.013 & 0.00 & 0.69 & $0.0001 * * *$ \\
\hline \%healthy+unhealthy WBP & 0.634 & 0.23 & 0.33 & $0.015^{*}$ \\
\hline$\%$ dead WBP & -0.520 & 0.25 & 0.19 & 0.060 \\
\hline \%healthy WBP+(\%healthy WBP $)^{2}$ & $-0.957+0.026$ & $0.66,0.01$ & 0.70 & $<0.001 * * *$ \\
\hline \multicolumn{5}{|l|}{ Correlation between measures of seed source health } \\
\hline \%healthy WBP $\mid$ healthy WBP BA $\left(\mathrm{m}^{2} \mathrm{ha}^{-1}\right)$ & 1.708 & 0.41 & 0.56 & $0.001^{* *}$ \\
\hline \%healthyWBP | mean WBP crown kill (\%) & -1.001 & 0.13 & 0.81 & $<0.001 * * *$ \\
\hline Healthy WBP BA $\left(\mathrm{m}^{2} \mathrm{ha}^{-1}\right) \mid$ mean WBP crown kill (\%) & -0.352 & 0.10 & 0.47 & $0.004 * *$ \\
\hline
\end{tabular}


Table 3. Summary of generalized linear mixed model $($ GLMM, family $=$ binomial, link $=$ logit $)$ predicting probability of whitebark pine seedling presence at plots located throughout 15 burns in Montana, USA.

\begin{tabular}{|c|c|c|c|}
\hline $\begin{array}{l}\text { Model and fixed effects } \\
\text { (study area=random effect) }\end{array}$ & Coefficients & SE & $\boldsymbol{P}$ \\
\hline \multicolumn{4}{|l|}{ Full model } \\
\hline Heatload Index & $-2.169 e-01$ & $1.390 \mathrm{e}+00$ & 0.8759 \\
\hline RdNBR & $3.543 \mathrm{e}-04$ & $5.355 \mathrm{e}-04$ & 0.5082 \\
\hline Topographic Convergence Index (TCI) & $-7.475 \mathrm{e}-02$ & $8.732 \mathrm{e}-02$ & 0.3920 \\
\hline Potential Solar Radiation $\left(\mathrm{Wh} / \mathrm{m}^{2}\right)$ & $-3.942 \mathrm{e}-06$ & $1.728 \mathrm{e}-06$ & $0.0226^{*}$ \\
\hline Distance to Seed Source (m) & $-7.104 \mathrm{e}-03$ & $1.867 \mathrm{e}-03$ & $0.0001 * * *$ \\
\hline Distance to Seed Source ${ }^{2}$ & $6.316 \mathrm{e}-06$ & $1.794 \mathrm{e}-06$ & $0.0004 * * *$ \\
\hline Vegetation Cover $(\%)$ & $7.486 \mathrm{e}-02$ & $2.833 \mathrm{e}-02$ & $0.0082 * *$ \\
\hline Vegetation Cover ${ }^{2}$ & $-1.085 \mathrm{e}-03$ & $3.229 \mathrm{e}-04$ & $0.0008 * * *$ \\
\hline \multicolumn{4}{|l|}{ Final, reduced model } \\
\hline Potential Solar Radiation $\left(\mathrm{Wh} / \mathrm{m}^{2}\right)$ & $-4.346 \mathrm{e}-06$ & $1.337 \mathrm{e}-06$ & $0.0012 * *$ \\
\hline Distance to Seed Source (m) & $-5.993 e-03$ & $1.628 \mathrm{e}-03$ & $0.0002 * * *$ \\
\hline Distance to Seed Source ${ }^{2}$ & $5.367 \mathrm{e}-06$ & $1.626 \mathrm{e}-06$ & $0.0097 * * *$ \\
\hline Vegetation Cover $(\%)$ & $5.948 \mathrm{e}-02$ & $2.548 \mathrm{e}-02$ & $0.0196^{*}$ \\
\hline Vegetation Cover ${ }^{2}$ & $-8.759 e-04$ & $2.786 \mathrm{e}-04$ & $0.0017 * *$ \\
\hline
\end{tabular}

Table 4. Summary of whitebark pine regeneration data from 15 burn study areas in Montana, USA, in order of decreasing seed source health. WBP refers to whitebark pine.

\begin{tabular}{|c|c|c|c|c|c|c|c|c|}
\hline Site & $\begin{array}{c}n \\
\text { plots }\end{array}$ & $\begin{array}{c}\text { Healthy } \\
\text { WBP in seed } \\
\text { source }(\%)\end{array}$ & 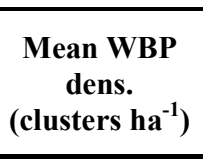 & $\begin{array}{c}\text { WBP SD } \\
\text { (clusters } \\
\text { ha }^{-1} \text { ) }\end{array}$ & $\begin{array}{c}\text { WBP SE } \\
\text { (clusters } \\
\text { ha }^{-1} \text { ) }\end{array}$ & $\begin{array}{c}\text { Normalized } \\
\text { WBP dens. } \\
\text { (clusters } \\
\text { ha }^{-1} \mathrm{yr}^{-1} \text { ) } \\
\end{array}$ & $\begin{array}{l}\text { Normalized } \\
\text { WBP SD } \\
\text { (clusters } \\
\mathrm{ha}^{-1} \mathrm{yr}^{-1} \text { ) } \\
\end{array}$ & $\begin{array}{c}\text { Normalized } \\
\text { WBP SE } \\
\text { (clusters } \\
\text { ha }^{-1} \mathbf{y r}^{-1} \text { ) } \\
\end{array}$ \\
\hline Pettengill & 44 & 65.1 & 515 & 687.5 & 103.6 & 85.9 & 114.6 & 17.3 \\
\hline Mussigbrod & 51 & 62.2 & 614 & 1048.5 & 146.8 & 61.4 & 104.9 & 14.7 \\
\hline Fall Fork & 40 & 60.5 & 650 & 1012.2 & 160 & 48.7 & 77.9 & 12.3 \\
\hline Red Owl & 22 & 43.3 & 273 & 428.9 & 91.4 & 13.6 & 21.4 & 4.6 \\
\hline Charlotte Pk & 23 & 40.9 & 783 & 735.9 & 153.4 & 41.2 & 38.7 & 8.1 \\
\hline Wyman & 30 & 26.7 & 0 & 0 & 0 & 0 & 0 & 0 \\
\hline Beaver & 48 & 26.7 & 389 & 712.4 & 102.8 & 32.4 & 59.4 & 8.6 \\
\hline Bighorn Lk & 80 & 22.5 & 508 & 836.9 & 93.6 & 23.1 & 38 & 4.3 \\
\hline Skalkaho & 40 & 20.3 & 167 & 362 & 57.2 & 12.8 & 27.8 & 4.4 \\
\hline Monitor & 30 & 16.7 & 44 & 169.1 & 30.9 & 2 & 7.7 & 1.4 \\
\hline Gates Park & 39 & 14.0 & 615 & 1063.9 & 170.4 & 26.8 & 46.3 & 7.4 \\
\hline Challenge & 32 & 13.3 & 0 & 0 & 0 & 0 & 0 & 0 \\
\hline Ann & 50 & 7.7 & 480 & 762.4 & 107.8 & 26.7 & 42.4 & 5.9 \\
\hline Monture & 50 & 2.7 & 160 & 394.1 & 55.7 & 14.5 & 35.8 & 5.1 \\
\hline Helen Creek & 48 & 1.6 & 177 & 282.3 & 40.7 & 17.7 & 28.2 & 4.1 \\
\hline
\end{tabular}




\section{Figure captions}

Figure 1. Map of study region showing the location of 15 study areas across Montana, USA. Shaded areas indicate National Forest; the Continental Divide is shown for reference.

Figure 2. Study area layout. All plots were sampled at or above the lower elevational limit of whitebark pine.

Figure 3. Boxplots of whitebark pine seedling density by study area, in order of decreasing seed source health, where the median is shown by the solid black line and the mean is shown by the solid black circle. Seedling density is normalized by number of years since fire.

Figure 4. Simple linear (4a), multiple linear (4b) and piecewise (4c) models reflecting the relationship between seed source health (percent of mature trees in the seed source that are healthy) and seedling density (seedlings ha ${ }^{-1}$ year $^{-1}$ ) in the adjacent burn. Standard error bars are shown. Solid vertical line in $4 \mathrm{c}$ is a potential threshold identified in the piecewise model.

Figure 5. Residuals with smoother curve from the top multiple linear model (Figure 4b) reflecting the relationship between seed source health (percent of mature trees in the seed source that are healthy) and seedling density in the adjacent burn (seedlings ha ${ }^{-1}$ year $^{-1}$ ).

Figure 6. Partial response curves from the GAMM that illustrate the influence of a) distance to seed source (DIST) $(\mathrm{m}), \mathrm{b})$ total vegetation cover (VEG) $(\%)$ and c) potential solar radiation (RAD) $\left(\mathrm{Wh} / \mathrm{m}^{2}\right)$ on the probability of whitebark pine seedling presence, while holding the other predictor variables at their mean. Gray shading is +/- 2 standard errors; residuals are shown.

Figure 7. Boxplots showing number of years post-fire until germination of sampled whitebark pine seedlings in five study areas that burned in the year 2000, and one study area (Pettengill) 
that burned in 2007, where the median is shown by the black line and the width of each boxplot is proportional to the sample size. Note the lag period of at least four years until the majority of germination occurs.

\section{Figures}

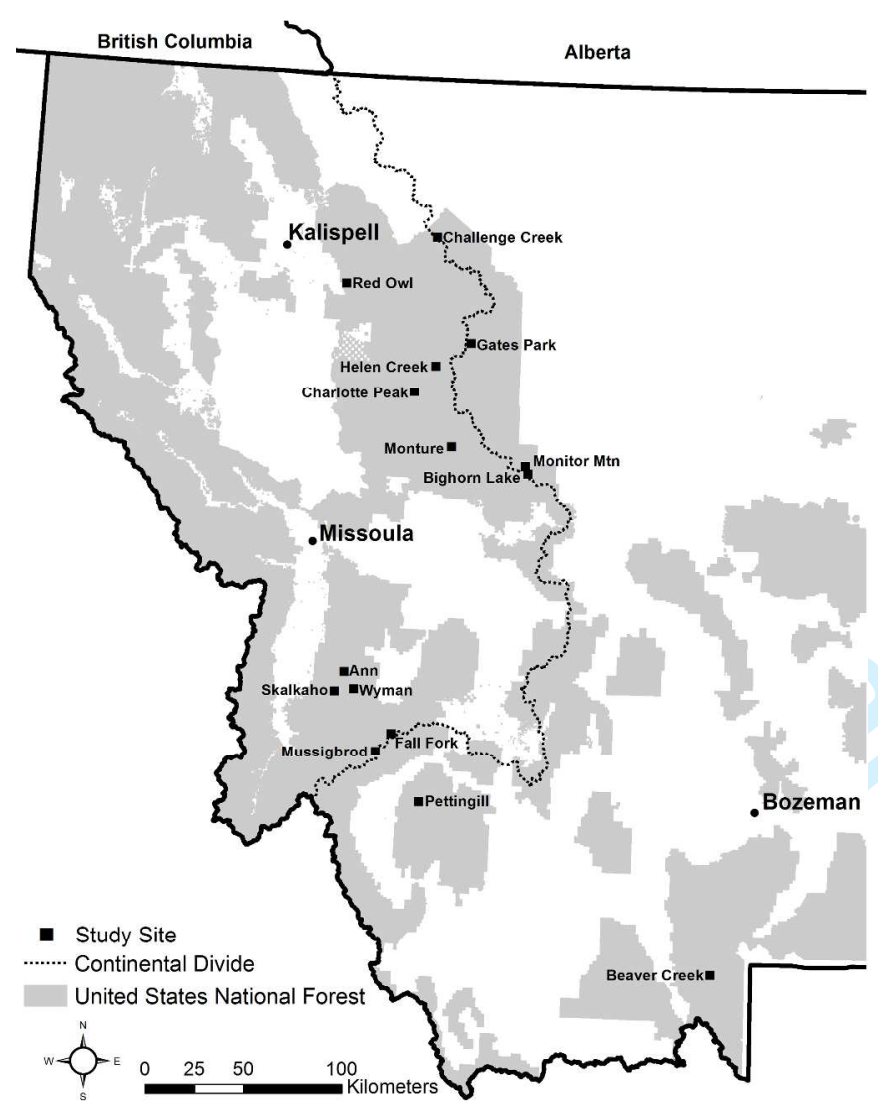




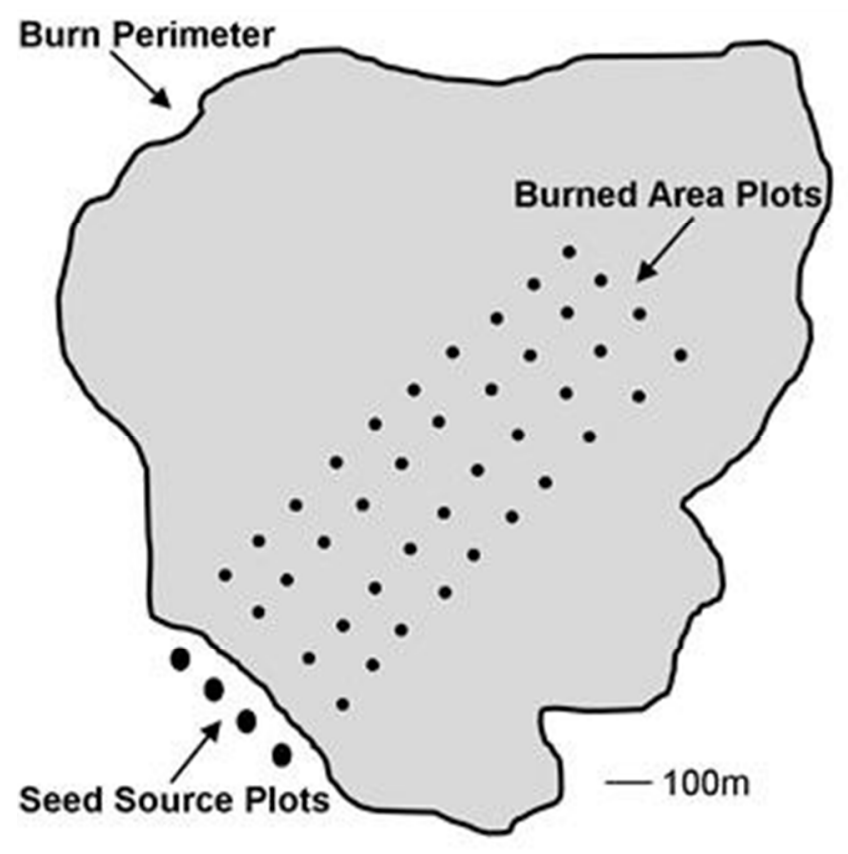




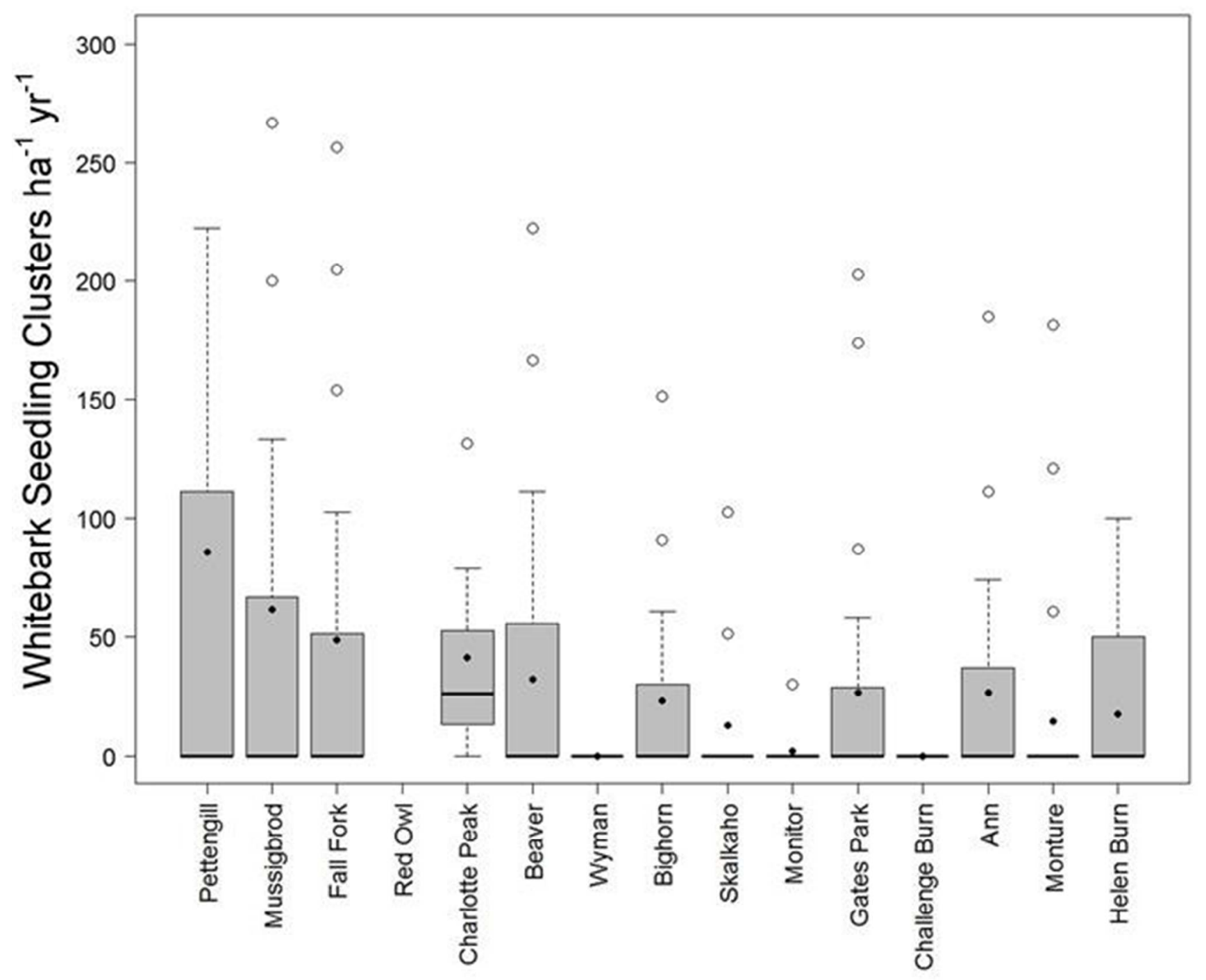



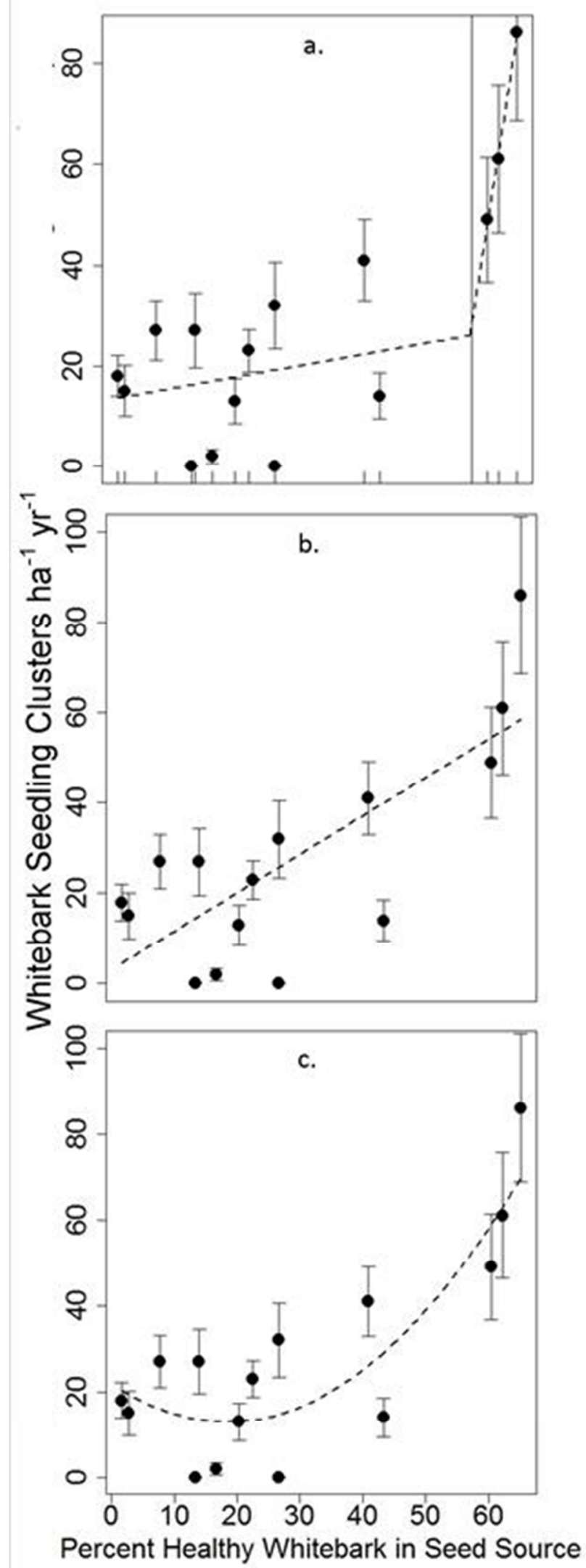


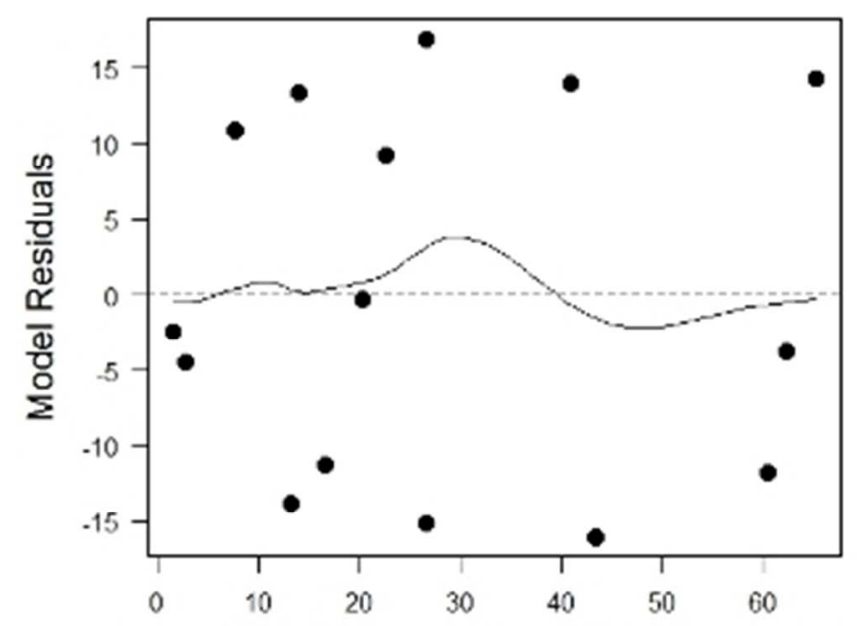

Percent Healthy Whitebark in Seed Source

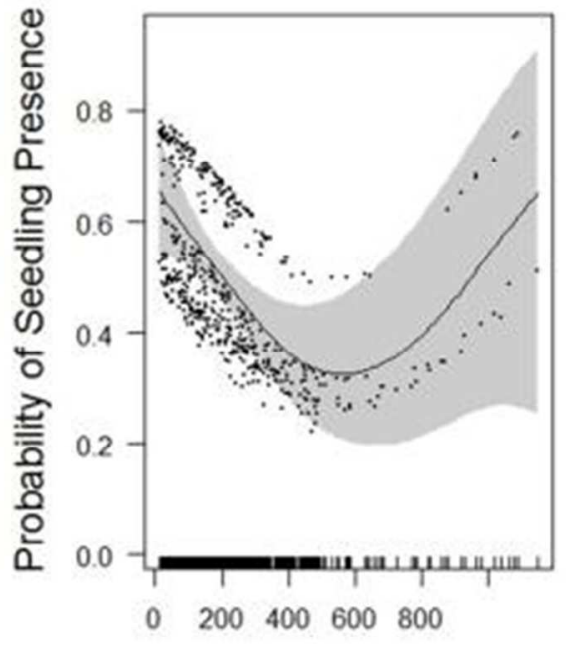

a. DIST

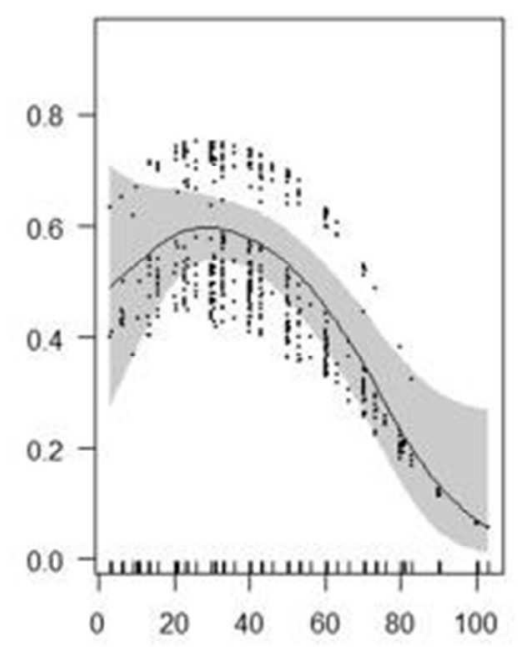

b. VEG

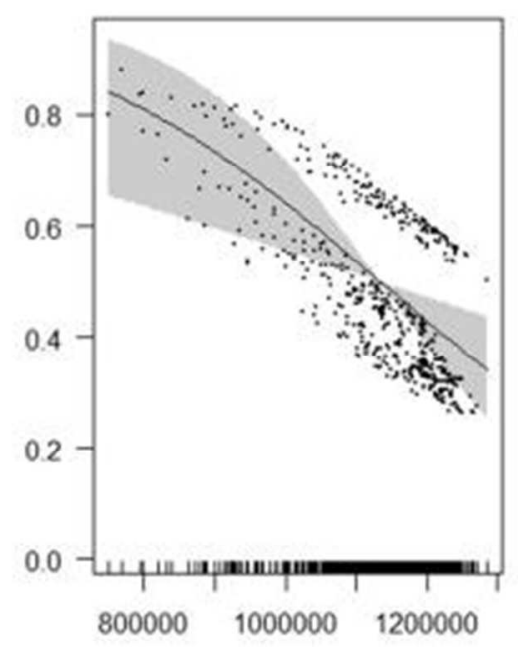

c. RAD 


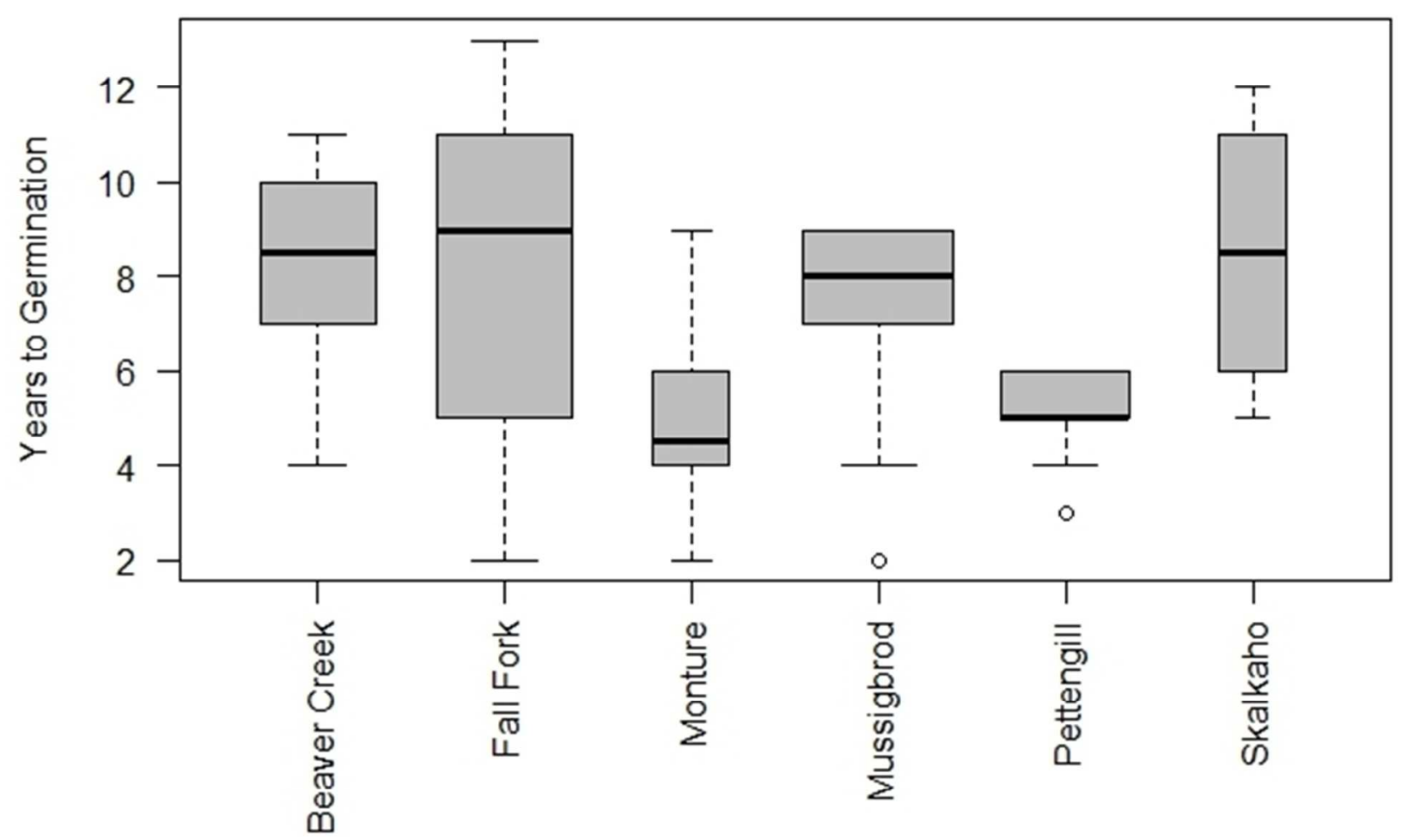

